\title{
STUDY ON THE ETHIOPIAN FRESHWATER MOLLUSCS, ESPECIALLY ON IDENTIFICATION, DISTRIBUTION AND ECOLOGY OF VECTOR SNAILS OF HUMAN SCHISTOSOMIASIS
}

\author{
Hiroshi Itagaki ${ }^{1}$, Noriji Suzuki ${ }^{2}$, Yoichi Ito 2 , \\ Takaaki Hara ${ }^{3}$ and Teferra Wonde 4 \\ Received for publication 17 February 1975
}

\begin{abstract}
Many surveys were carried out in Ethiopia from January 1969 to January 1971 to study freshwater molluscs, especially the intermediate and potential host snails of Schistosoma mansoni and S. haematobium, to collect their ecological data, and to clarify the distribution of the snails in the country. The gastropods collected consisted of two orders, the Prosobranchia and Pulmonata. The former order contained three families (Thiaridae, Viviparidae and Valvatidae) and the latter four families (Planorbidae, Physidae, Lymnaeidae and Ancylidae). The pelecypods contained four families: the Unionidae, Mutelidae, Corbiculidae and Sphaeriidae. Biomphalaria pfeifferi rueppellii and Bulinus (Physopsis) abyssinicus are the most important hosts of S. mansoni and S. haematobium respectively. The freshwater snail species could be grouped into two distibution patterns, one of which is ubiquitous and the other sporadic. B. pfeifferi rueppellii and Bulinus sericinus belong to the former pattern and Biomphalaria sudanica and the members of the subgenus Physopsis to the latter. Pictorial keys were prepared for field workers of schistosomiasis to identify freshwater molluscs in Ethiopia. Habitats of bulinid and biomphalarian snails were ecologically surveyed in connection with the epidemiology of human schistosomiasis. Rain falls and nutritional conditions of habitat appear to influence the abundance and distribution of freshwater snails more seriously than do temperature and $\mathrm{pH}$, but water current affects the distribution frequently. Slight pollution of water brought about by immigration of people with their domestic animals under reclamation plans of land often results in abundance of snails in the waters and subsequently new endemic foci of schistosomiasis.
\end{abstract}

Two species of human schistosomes are endemic in Ethiopia: Schistosoma manson and S. haematobium. Some species of freshwater snails of the genera Biomphalaria and Bulinus are known as the intermediate hosts of these blood flukes in various parts of Africa. But, it has been insufficiently examined in Ethiopia what species of Bulinus and Biomphalaria act as the intermediate hosts and how wide they are

1 Dept. of Parasitology, Azabu Veterinary College, Fuchinobe, Sagamihara 229, Japan. 2 Dept. of Parasitology, National Institute of Health, Kamiosaki, Shinagawa, Tokyo, Japan. 3 Tokyo Association of Health Service, c/o Hokenkaikan, Ichigaya-Sadohara, Shinjuku, Tokyo, Japan. 4 Dept. of Medical Zoology, the Imperial Central Laboratory and Research Institute, P. O. B. 1242, Addis Ababa, Ethiopia. 
distributed in the country. Ayad (1956), Brown (1964, 1965), Burch (1965) and others conducted surveys to collect the molluscan intermediate hosts and to know their distribution in Ethiopia, which, however, did not sufficiently cover broad range enough to elucidate the state of the case.

During the stay in Ethiopia surveys were many times undertaken to know the distribution and habitat conditions of the intermediate and potential snail hosts of the human schistosomes in this area. In surveys and experiments on medical and veterinary important flukes such as the schistosome, common liver fluke and paramphistome, it is frequently a troublesome task for parasitologists, physicians and veterinarians to identify intermediate host snails, because they have few characteristics available to discriminate each other. Meskal (1967) prepared an identification key of Ethiopian freshwater gastropods which had been known in the country, but the key was not pictorial. Hence an attempt was made to prepare the pictorial keys of Ethiopian freshwater molluscs for field work.

\section{Materials ANd Methods}

The surveys were carried out through the country from January 1969 to January 1971.

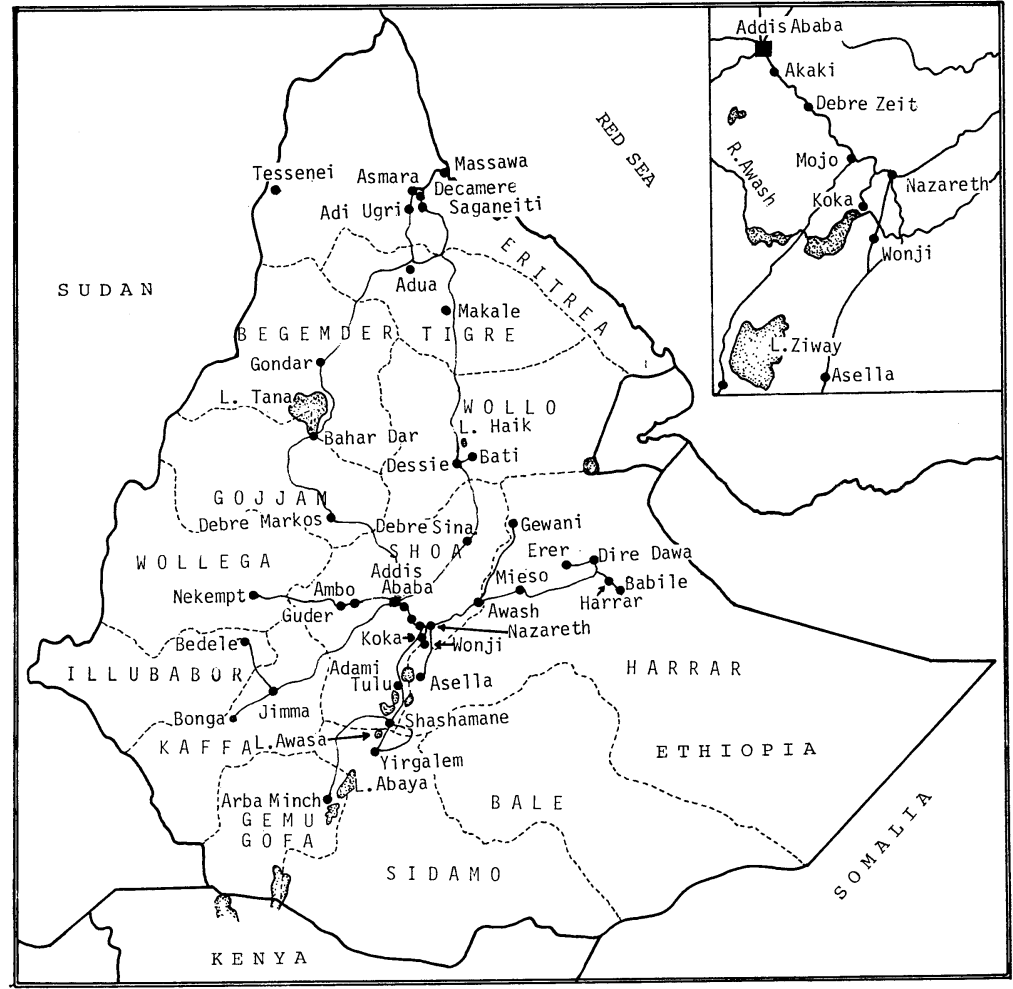

Fig. 1 Ethiopia. Boundaries of provinces indicated by broken lines; routes followed in making the present collection indicated by solid lines. 
The collecting loci of molluscs amounted to 336 in number, which are distributed principally along the main all-weather roads (Fig. 1). All the molluscan specimens collected were identified and ecological data of the habitats were recorded in regard to $\mathrm{pH}$ and water temperature, associated plants and animals, pollution of water, and so on. $\mathrm{pH}$ was principally obtained by measurement with $\mathrm{pH}$ indicator papers.

The snails collected were identified by shell characteristics alone, and Brown (1965) was principally followed in the present study to identify and classify Ethiopian gastropods.

\section{RESUlts}

1. Freshwater molluscs collected

The present survey revealed the occurrence of the following freshwater molluscs in Ethiopia including gastropods and pelecypods. The gastropoda consisted of two orders of the Prosobranchia and Pulmonata. The former order contained three families: Thiaridae, Viviparidae and Valvatidae and the latter did the four families of Planorbidae, Physidae, Lymnaeidae and Ancylidae. The family Planorbidae contained at least six genera of Bulinus, Biomphalaria, Anisus, Gyraulus, Segmentorbis and Armiger, and the genera Bulinus and Biomphalaria include the hosts of the human schistosomes. The Pelecypoda consisted of the following genera of Pisidium, Sphaerium and Etheria, together with at least one unnamed species of the family Unionidae and two species of Corbiculidae (Table 1).

TABLE 1 Ethiopian freshwater molluscs collected in the present survey

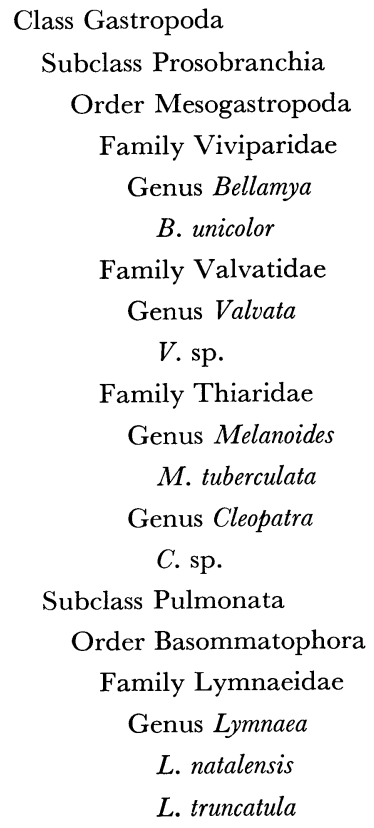


Family Planorbidae

Genus Bulinus
B. (Bulinus) sericinus
B. (B.) forskalii
B. (B.) sp.
B. (Physopsis) africanus ovoideus
B. (P.) ugandae
B. $(P$.) abyssinicus

Genus Biomphalaria

B. pfeifferi rueppellii

B. sudanica

Genus Anisus

A. natalensis

A. coretus

Genus Gyraulus

G. castulatus

Genus Segmentorbis

S. angustus

Genus Armiger

A. crista

Family Physidae

Genus Physa

$P$. sp.

Family Ancylidae

Genus Burnupia

B. caffra

Genus Ferrissia

$F$. clessineana

Genus Ancylus

$A$. sp.

Class Pelecypoda

Family Unionidae

An unnamed species

Family Mutelidae

Genus Etheria

E. elliptica

Family Corbiculidae

Two unnamed species

Family Sphaeriidae

Genus Sphaerium

S. sp.

Genus Pisidium

$$
P \text {. sp. }
$$


TABLE 2 Classification of Ethiopian freshwater mollusca

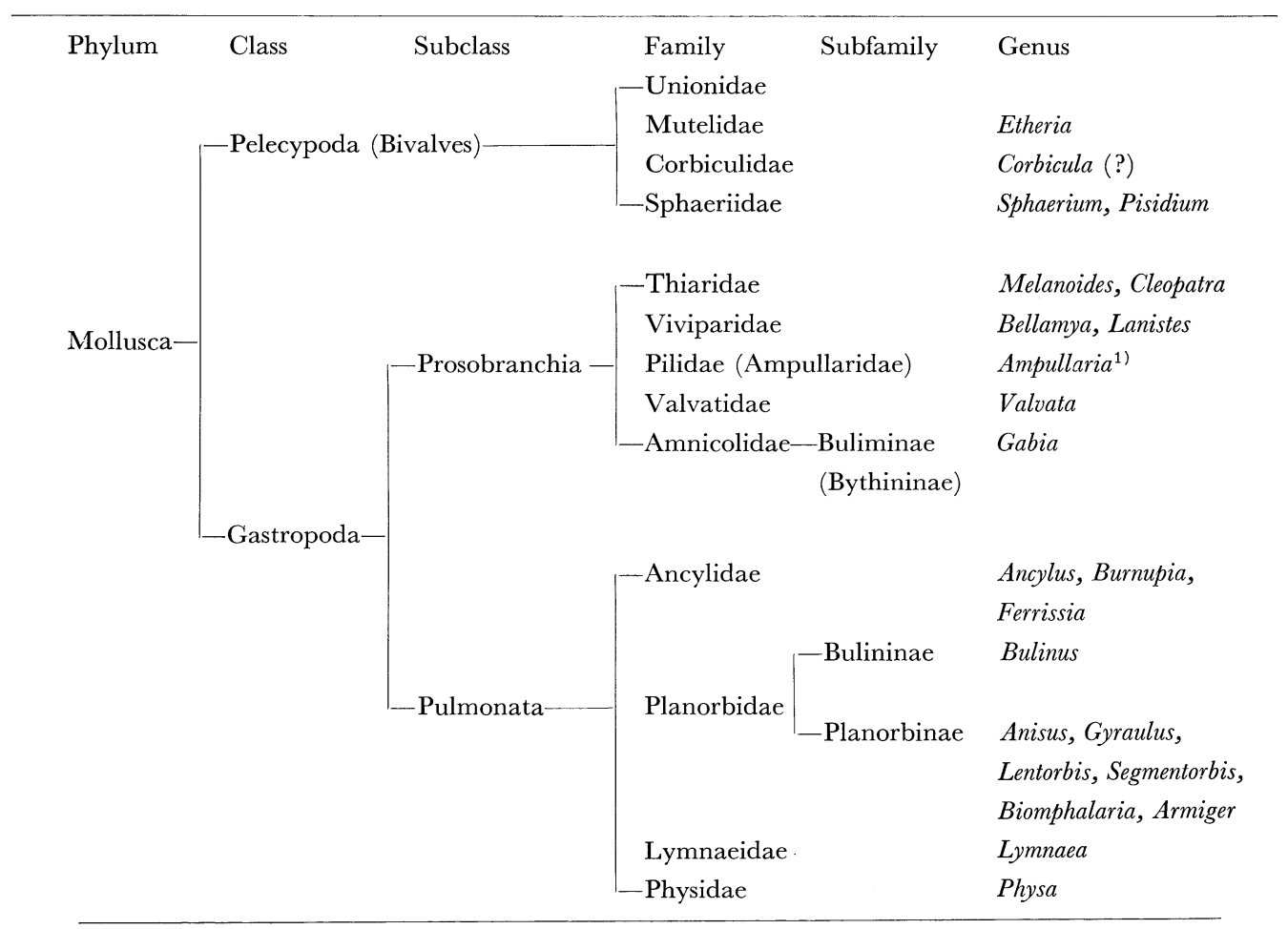

1 Empty shells of Ampullaria were collected by Brown (1965)

2. The intermediate and suspected snail hosts of the human schistosomes and their distribution in Ethiopia

The genera of Bulinus and Biomphalaria contain the species incriminated as the intermediary hosts of Schistosoma haematobium and S. mansoni respectively.

Two species of Biomphalaria were collected: B. pfeifferi rueppellii and B. sudanica. The former species is the most important snail host of $S$. mansoni in Ethiopia, while the latter is of very little importance as the host. S. haematobium, on the other hand, has been reported to be transmitted by Bulinus snails in various parts of the African continent. The genus Bulinus is usually composed of two subgenera, Bulinus and Physopsis. At least six species of the subgenus Bulinus have been reported from Ethiopia: B. (B.) sericinus, B. (B.) forskalii, B. (B.) scalaris, B. (B.) hexaploidus, B. (B.) octoploidus and $B$. (B.) sp., and the subgenus Physopsis includes three species in Ethiopia: $B .(P$.$) abyssinicus, B .(P$.$) africanus ovoideus and B .(P$.$) ugandae. Of these species,$ $B$. $(P$.) abyssinicus is the only confirmed snail host of $S$. haematobium in the country.

The freshwater snails have different distribution patterns in Ethiopia according to the species. Speaking roughly, some species have a ubiquitous distribution throughout the country and some are sporadic in distribution. Bulinus sericinus and Biomphalaria pfeifferi rueppellii, for example, belong to the former pattern of distribution, 
whereas the members of the subgenus Physopsis, the forskalii group complex of the subgenus Bulinus and Biomphalaria sudanica to the latter pattern. Bulinus sericinus was mainly distributed in the areas around Addis Ababa, along the Asmara road from Addis Ababa to Lake Haik, and around Lake Tana and Harer (Fig. 2), while Biom-

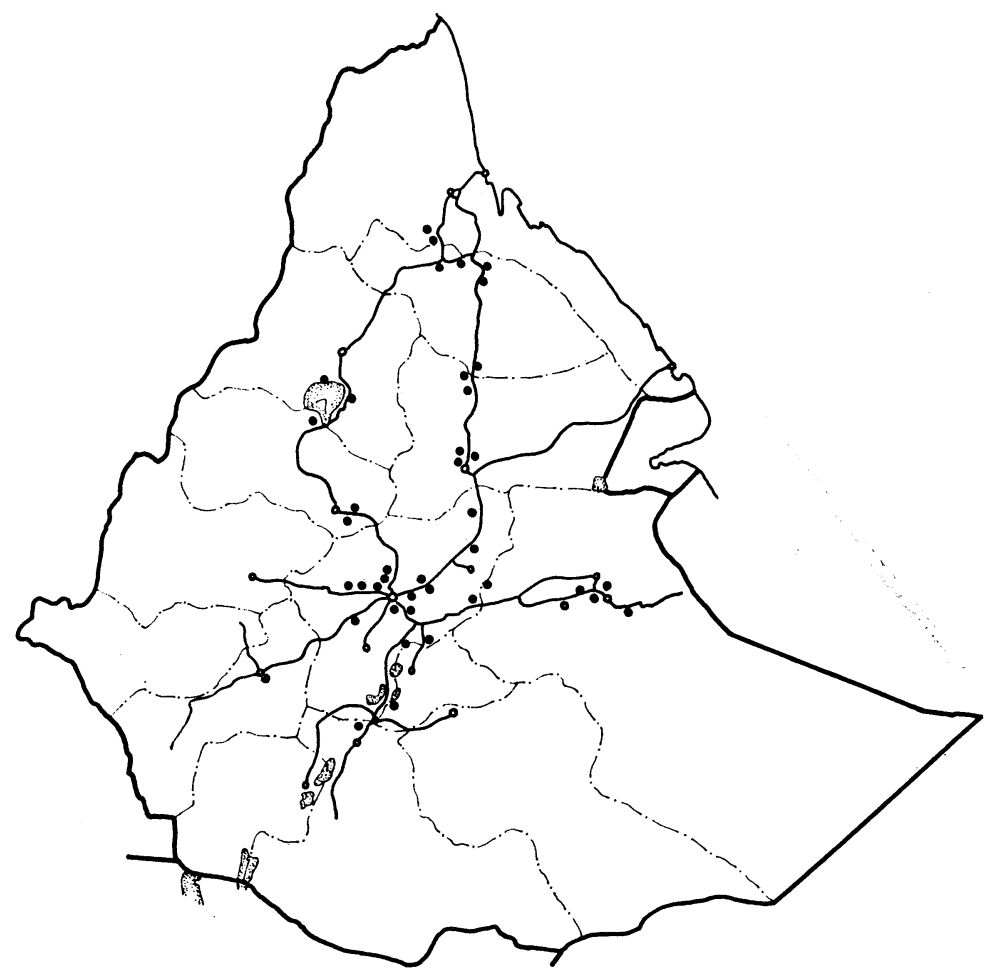

Fig. 2 Distribution of Bulinus (Bulinus) sericinus in Ethiopia.

phalaria pfeifferi rueppellii in the areas along the all-weather roads except the areas between Lake Haik and Makale, from Gondar to the border between the Tigre and Begemder provinces, between Debre Markos and Lake Tana, and Nazareth to Mieso (Fig. 3). The areas without any species of freshwater snails have no bodies of water suitable for the snails to inhabit. Biomphalaria sudanica was limited in distribution to some of the Great Rift Valley lakes area (the lakes of Ziway, Awasa and Abaya) and to a separated focus at the Artuma Bilu river (a tributary of the Awash river) about the midst between Debre Sina and Dessie (Fig. 4). Bulinus (P.) africanus ovoideus was collected at some foci in the north-east part of the country, principally along the main road from Bahar Dar to Asmara and in the Little Gibe river on the road from Addis Ababa to Jimma (Fig. 5). Bulinus (P.) ugandae and B. (P.) abyssinicus have a sporadic distribution; the former species was found in Beda Buna (a swamp near Jimma) and Lake Abaya and the latter at Gewani and Ofonofei in the Lower Awash Valley (Fig. 5). Bulinus (B.) sp. described by Brown (1965) was also found restrictedly in the Great Rift Valley lakes area (Fig. 6) and B. (B.) forskalii 

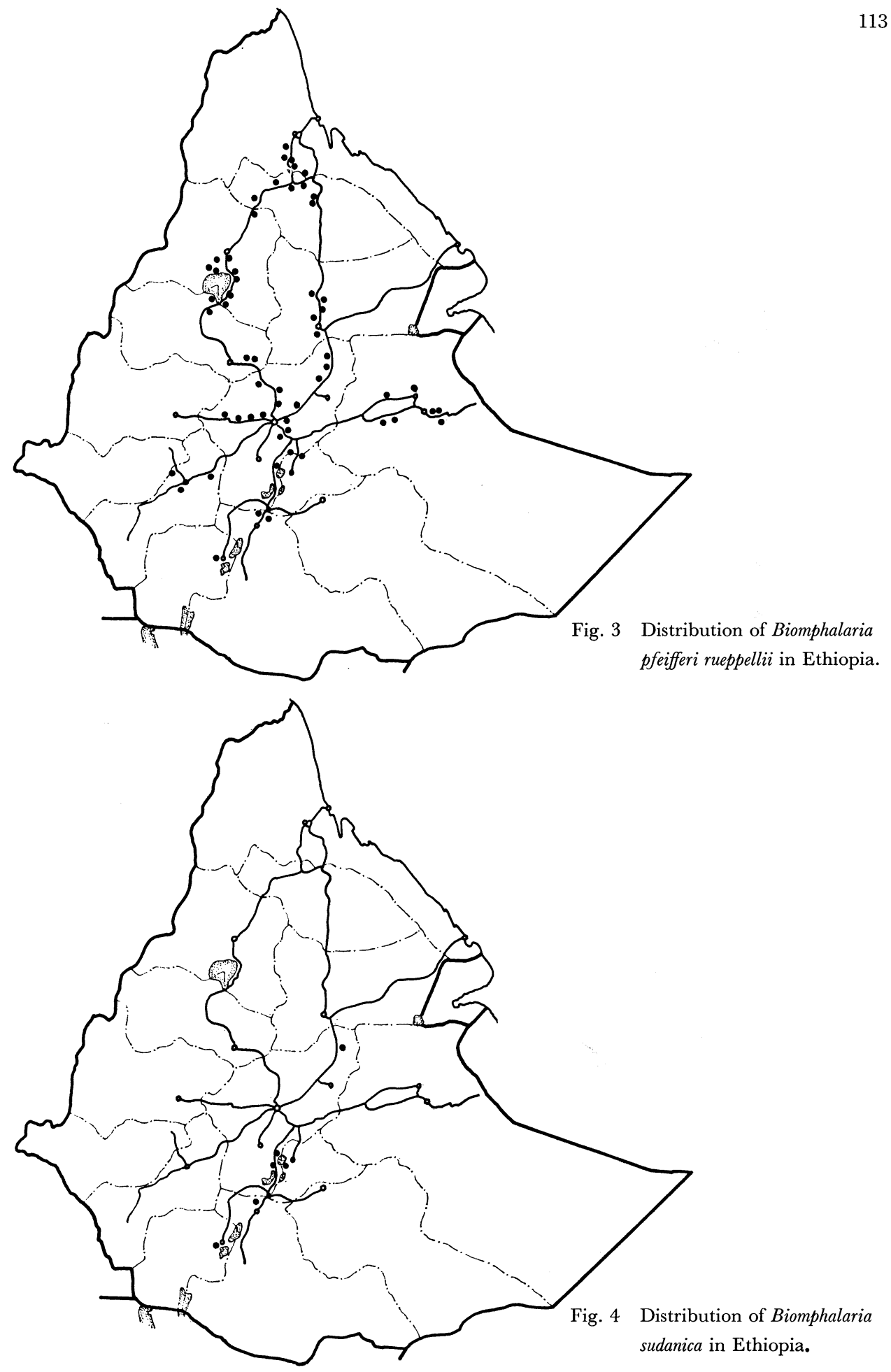


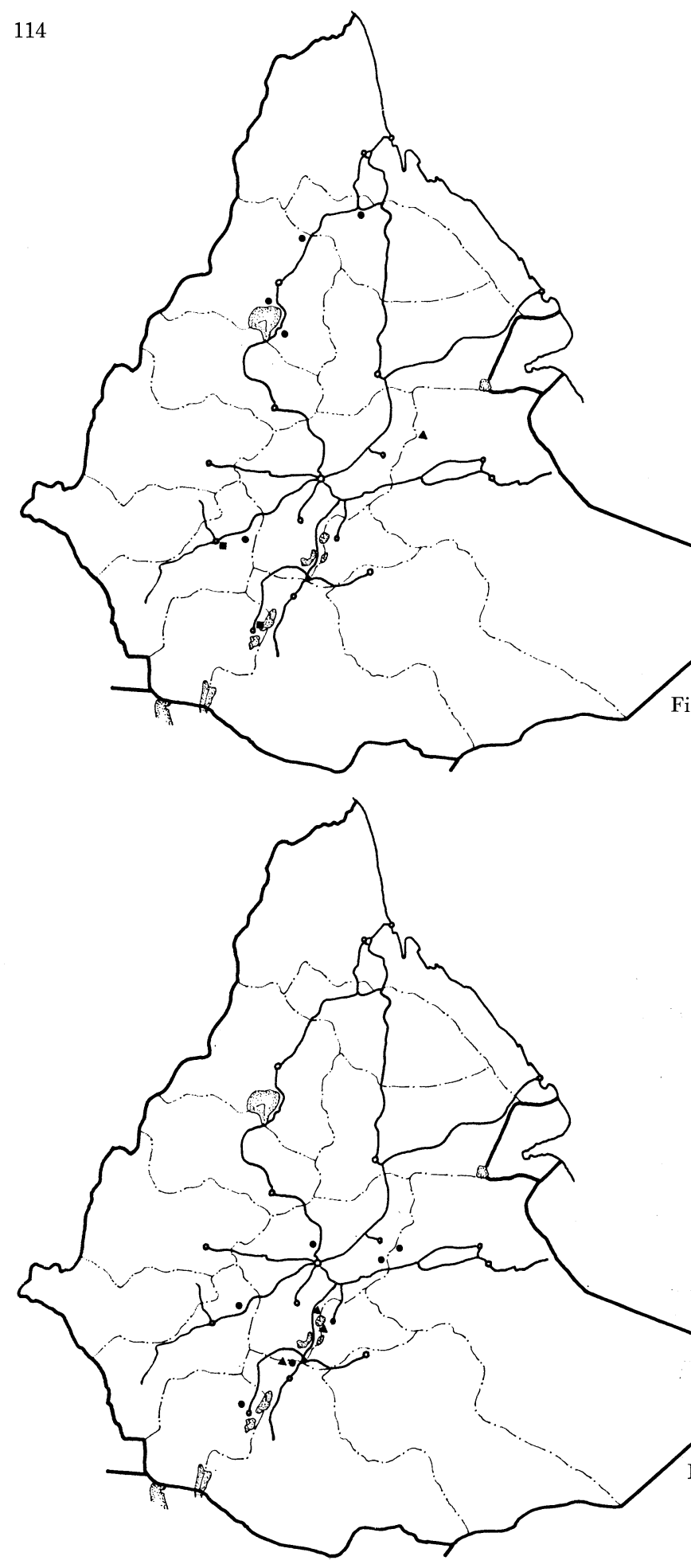

Fig. 5 Distribution of Bulinus

(Physopsis) abyssinicus (triangle), $B .(P$.) ugandae (square) and $B .(P$.$) africanus ovoideus$ (circle).

Fig. 6 Distribution of Bulinus (Bulinus) forskalii (circle) and $B$. (B.) sp. (triangle). 
was also sporadic in distribution (Fig. 6). No snails were found in the area between Nazareth and Awash where no permanent bodies of water exist except for a few alkaline lakes.

3. Environmental factors in snail habitats and their correlation with prevalence of schistosomiasis

Water temperature of habitat ranged from 9.5 to $31.5 \mathrm{C}$ with the maximum frequency near 15 and $22 \mathrm{C}$ in both of the cases of Bulinus and Biomphalaria, and higher temperatures may be more suitable for Biomphalaria than for Bulinus (Figs. 7, 8). Bulinus, in general, has a tendency to tolerate the wider range of $\mathrm{pH}$ than Biomphalaria,

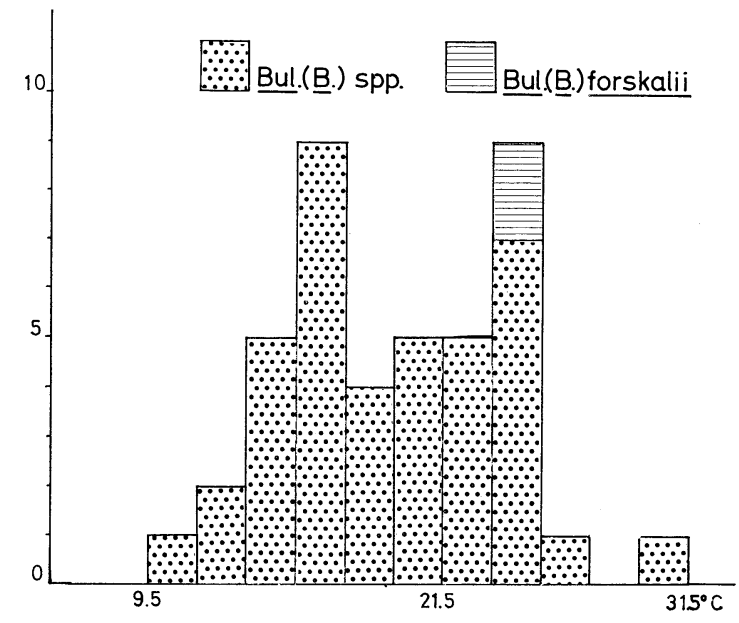

Fig. 7 Histogram showing range of water temperatures of habitats of Bulinus snails and frequency (number of localities).

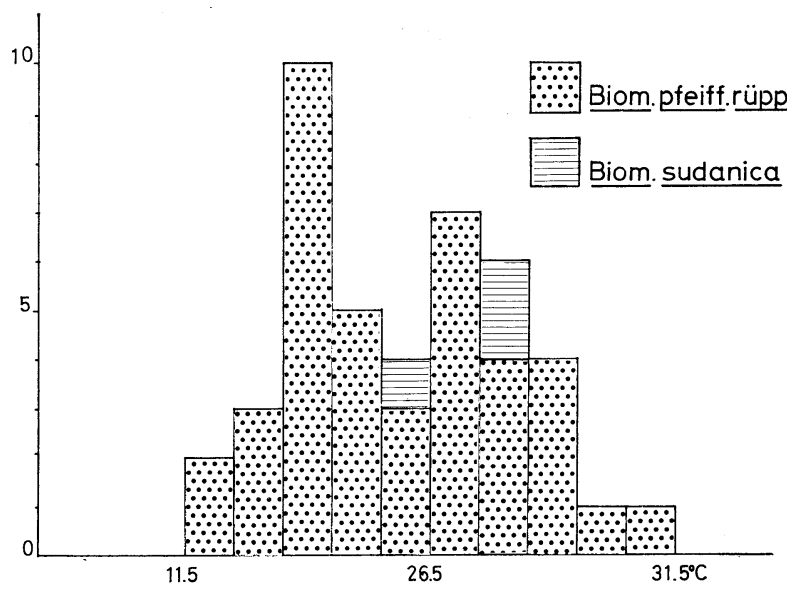

Fig. 8 Histogram showing temperature range of habitats of Biomphalaria snails and frequency. 
that is, $\mathrm{pH}$ range was from 5.3 to 9.5 in the case of Bulinus and from 5.4 to 7.8 in Biomphalaria, with the maximum frequency in $\mathrm{pH}$ ranges of 5.0 to 6.2 and of 6.6 to 7.8 respectively. Consequently hydrogen ion concentration appears rarely to be a limiting factor of the distribution (Figs. 9, 10).

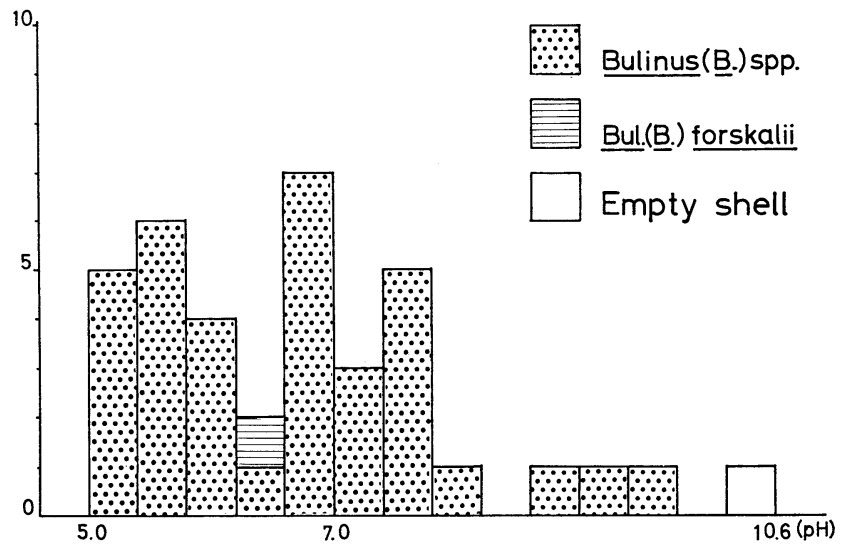

Fig. 9 Showing $\mathrm{pH}$ range of habitats of Bulinus spp. and frequency.

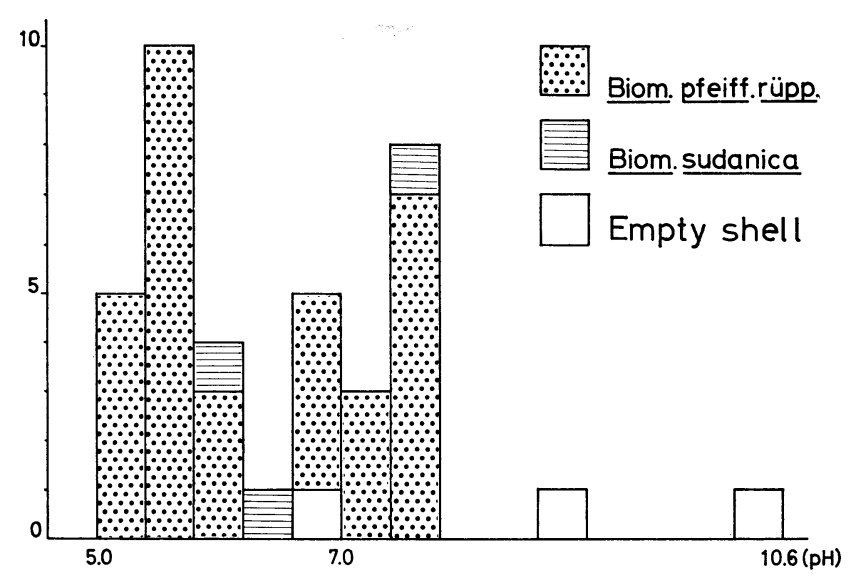

Fig. 10 Histogram showing $\mathrm{pH}$ range of habitats of Biomphalaria spp.

Two main factors responsible for marked change in abundance of snails will be temperature and rainfall. The rainfall of Ethiopia is seasonal and varies in different parts of the country. The year can be divided into rainy and dry seasons. The rainy season usually consists of the 'little rains' from April to June and big rains from July to September. Freshwater pulmonate snails can breed in temporary waters too and snail populations rapidly increase after the start of rainy season.

Another factor for snails to breed is nutritional. The ability and willingness of the snail hosts to eat almost any organic material offered to them are largely res- 
ponsible for the correlation between human pollution and number of freshwater snails; in other words, mild pollution by the human has an enriching effect on the snails. The sites inhabited by a lot of Bulinus or Biomphalaria snails were often polluted slightly with domestic wastes, excreta of domestic animals and man, and so on; and waters containing much organic materials were frequently accompanied with a large quantity of floating, emersed or submersed vegetation. For example, into a farm along the Kella river near Shashamane many people have immigrated with their domestic animals to result in pollution of the streams where Biomphalaria snails crowded on muddy silt. Another example was observed in the Wonji Sugar Plantation where irrigation ditches had been constructed and many people, some of whom were infected with schistosomes, had migrated, so schistosomiasis masoni had come endemic and Biomphalaria snails were abundantly found in the ditches.

Another factor influencing snail inhabitation is water current. Bulinus, Biomphalaria, Lymnaea and Physa species were unusually collected from large and rapid streams such as the Hedie river near Guder, $143 \mathrm{~km}$ from Addis Ababa on the road to Ambo, the Gibe river and the Gojeb river on the Jimma road and the Awash river in the Awash National Game Reservoir, in most of which substratum was sandy or rocky and had no or scarce vegetation. The reason for this appears that the snails can not tolerate a high rate of flow and fast stream may wash away muddy silt which contains much of organic materials important as the food of bulinid and biomphalarian snails. Consequently, stream gradient seems to have an important influence on the distribution of those intermediate host snails.

Aquatic animals found with the snails do not always have direct ecological correlation with them, but sometimes they may be fair indicators of habitats suitable for the snails. Some species of molluscs were frequently collected with bulinines or biomphalarians. A high degree of association between Bulinus species and such small planorbids as Anisus and Gyraulus and a very low degree of association between Bulinus and Biomphalaria pfeifferi rueppellii make it possible to suggest that Bulinus has ecological requirements similar to the small planorbids and different from $B$. pfeifferi rueppellii. Biomphalaria sudanica, on the contrary, was frequently collected with Bulinus in habitats where luxriant aquatic vegetation was present. B. pfeifferi rueppellii appears to inhabit sites with much muddy silt containing organic materials and was often found associated with a small bivalve, Sphaerium sp.

Aquatic plants provide good surface for freshwater snails to feed on and lay eggs. Some species of the plants were observed to have a high degree of association with certain species of freshwater snail; the submersed vegetation such as Potamogeton crispus, the water weed Elodea sp., Chara sp., Hydrilla-like sp. and filamentous algae, the floating plants such as Potamogeton sp., Nymphaea and Lemna-like sp., Pygonum sp., Cradamine-like sp., and Commelina-like sp. were seen associated with Bulinus, Biomphalaria and Lymnaea. Bulinus forskalii was frequently collected on the undersides of floating leaves of Nymphaea in Lake Awasa. A few sites with luxuriant submersed vegetation and clean water were observed inhabited by many species of freshwater molluscs, for example, the Chacha river about $110 \mathrm{~km}$ from Addis Ababa on the road to Asmara and a small body of water $100 \mathrm{~km}$ from the capital on the road. 4. Keys of Ethiopian freshwater molluscs 
Freshwater molluscs, in general, are difficult to identify, because they have generally not so discriminative features as sea shells. For this reason it will be a necessary but troublesome job for parasitologists, physicians and veterinarians to identify the intermediary and potential host molluscs of human and veterinary important parasites, hence the keys of the host snails, especially the pictorial are useful for the purpose. Pictorial keys were prepared for the identification of important

\section{Shell Characteristics}
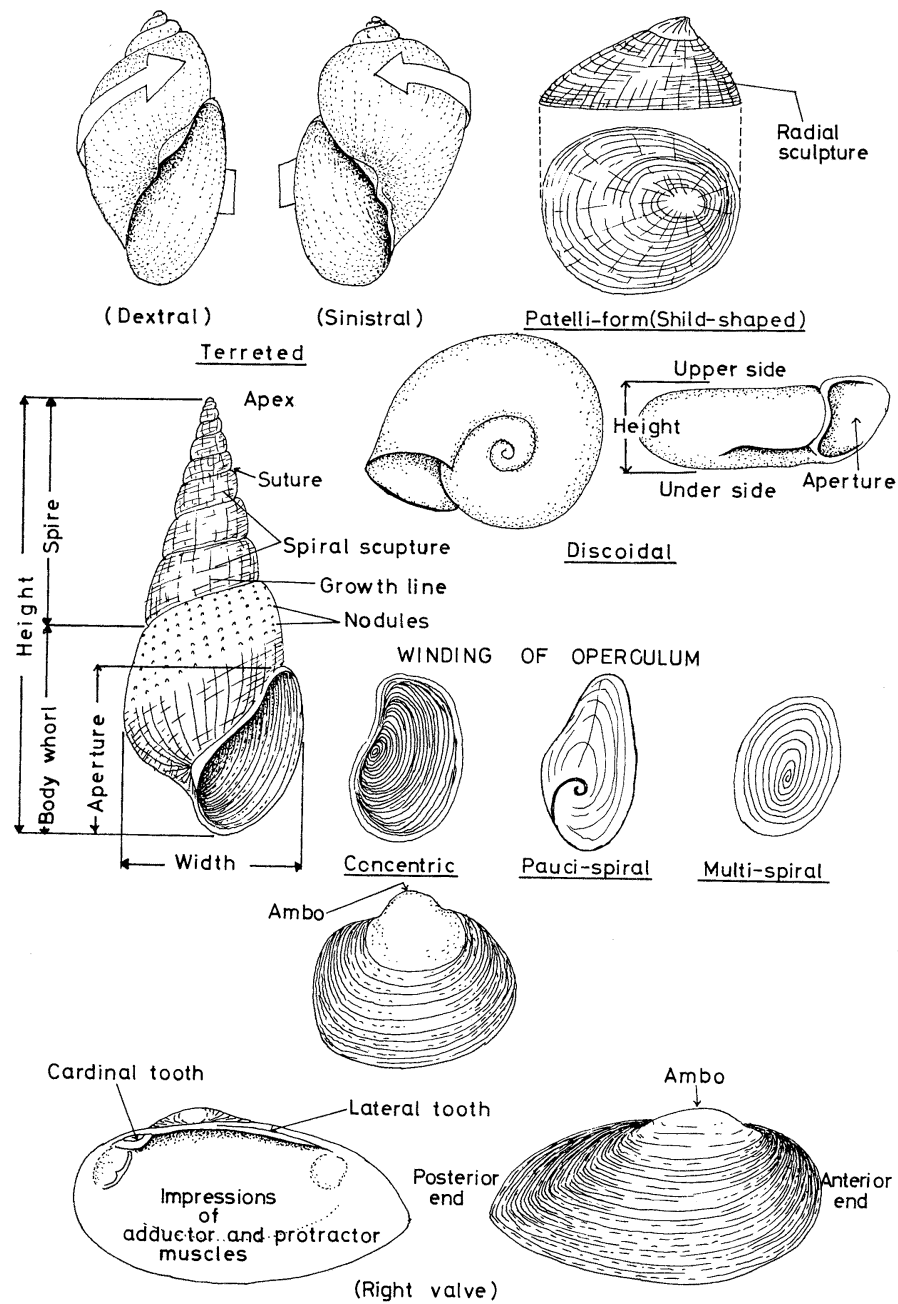

Fig. 11 Showing shell characteristics available for identification of molluscan species.

Ethiopian freshwater molluscs. The identification keys were principally based on shell characteristics for the purpose of field work and the freshwater molluscs reported from Ethiopia were delt with in the present keys (Figs. 11-15, Tables 3-6). 


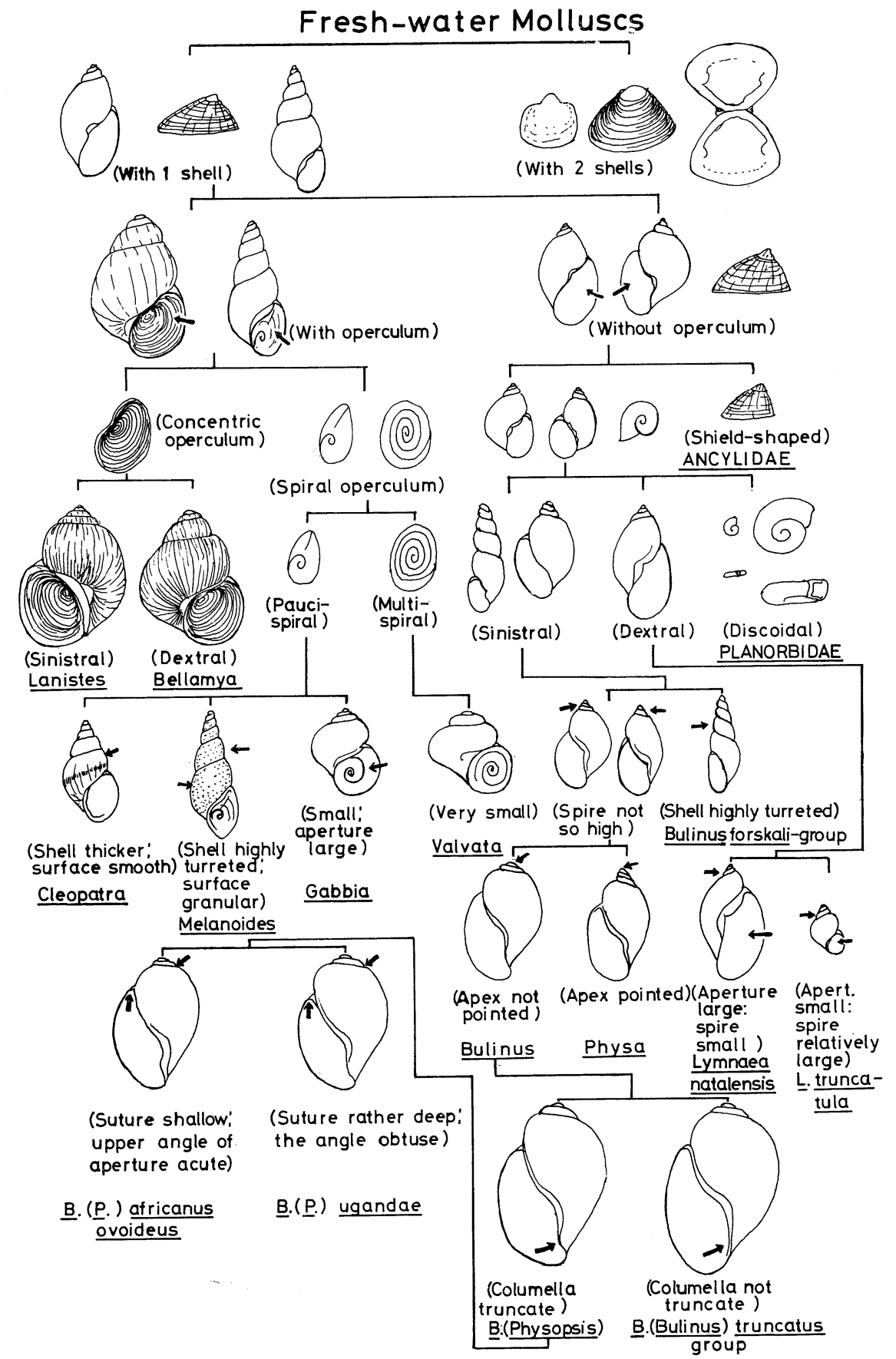

Fig. 12 Pictorial key to identification of Ethiopian freshwater molluscs. 


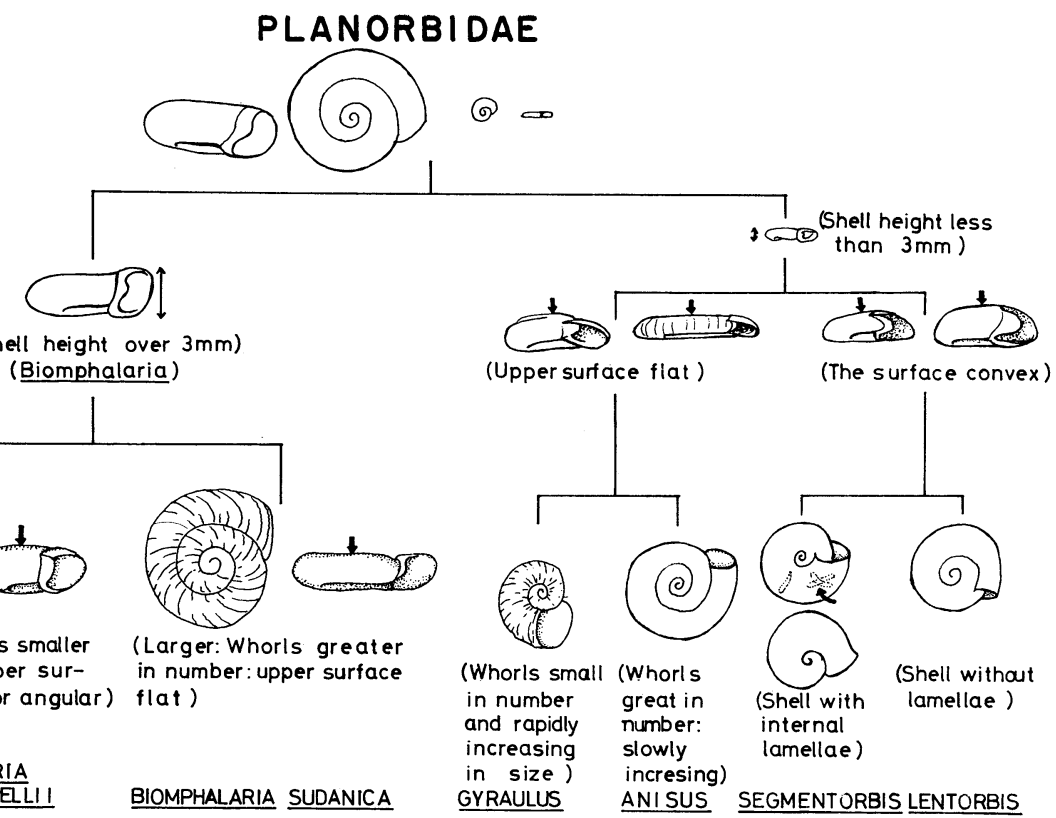

Fig. 13 Pictorial key to Ethiopian Planorbidae.

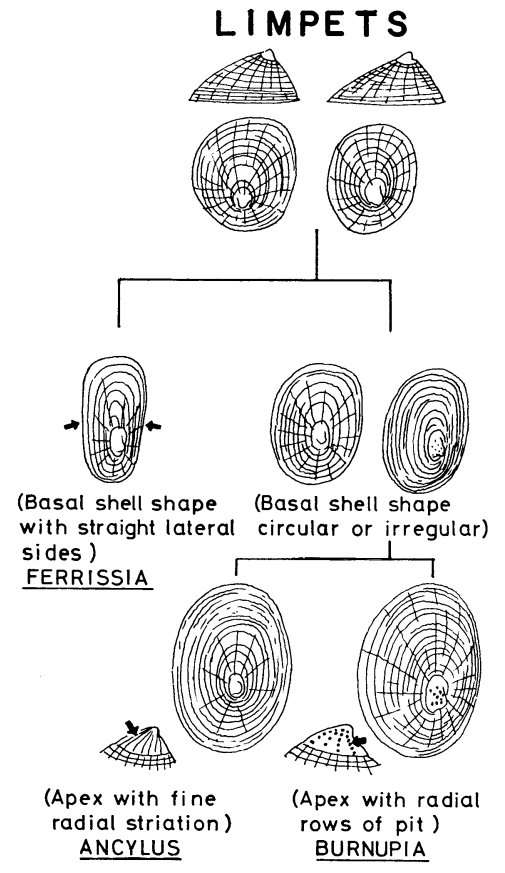

Fig. 14 Pictorial key to Ethiopian Ancylidae (limpets).

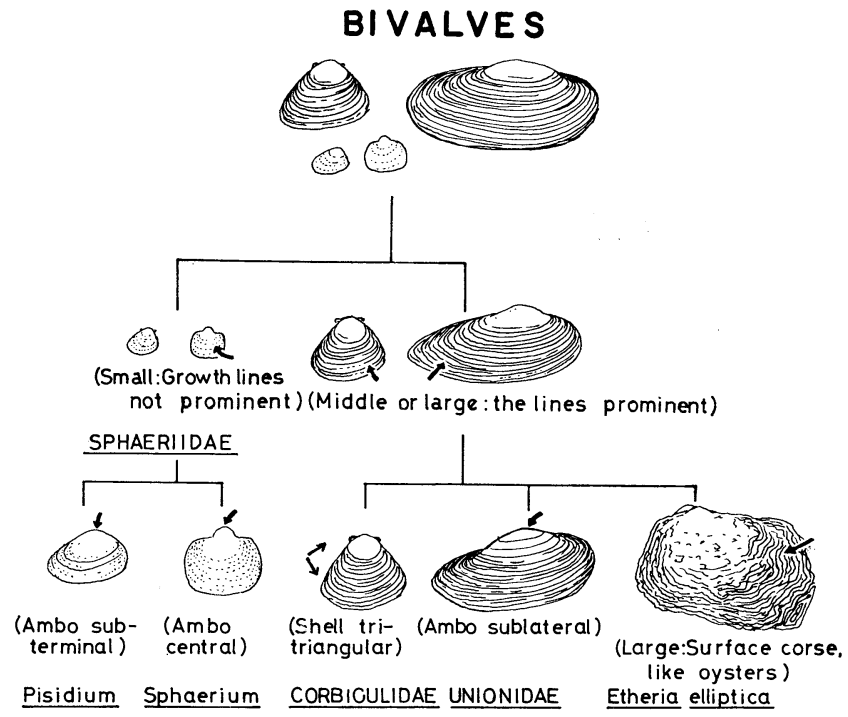

Fig. 15 Pictorial key to Ethiopian Pelecypoda (bivalves). 
TABLE 3 Key to the genera of Ethiopian freshwater mollusca

$1\left\{\begin{array}{l}\text { Sh } \\ \text { Sh }\end{array}\right.$

Shell two in number and dish-like

hell one in number and spiral or discoidal or shield-shaped .... 2 (Gastropoda)

(Fig. 12)

14 (Pelecypoda)

(Fig. 15)

(Shell usually thick and has a lid (=operculum); (radula has 7 teeth

2\{

Shell usually thin and has no lid; (radula more than 7 teeth in (the row; hermaphrodite)

3 (Prosobranchia)

9 (Pulmonata)

Operculum concentric; shell large, dextral or sinistral $\ldots \ldots \ldots 4$

Operculum spiral; shell middle or small, dextral $\ldots \ldots \ldots \ldots 6$

(Shell very large (up to $10 \mathrm{~cm}$ in height), often nearly globose,

$4\left\{\begin{array}{l}\text { smooth in surface; dextral or sinistral } \ldots \ldots \ldots \ldots \ldots \ldots \ldots \ldots \ldots \\ \text { Shell smaller (less than } 4 \mathrm{~cm} \text { ), broad conical; dextral; (right }\end{array}\right.$

tentacle of male acts as copulatory organ) $\ldots \ldots \ldots \ldots \ldots \ldots \ldots$

5 Shell dextral

Shell sinistral

Operculum multispiral; shell small in size.

6

Operculum paucispiral; shell small or middle (less than $2 \mathrm{~cm}$ in (height)

Shell turreted, surface tuberculate or not; whorls more than 4 in

$7\{$ r

Shell turreted, surface smooth; whorls less than $4 \ldots \ldots \ldots \ldots$

(Shell tuberculate on surface; (mantle edge fringed).

8 Shell surface often smooth or with few spiral ribs; (mantle edge (smooth)

Shell cap- or shield-shaped

9

Shell spiral

10

Shell turreted

Shell discoida

al $\ldots$

$\ldots \ldots \ldots \ldots \ldots \ldots \ldots \ldots \ldots \ldots \ldots \ldots \ldots \ldots$ 
Shell rather small $(7-12 \mathrm{~mm})$ with more slowly increasing whorls; spire as high as aperture; columella not obliquely folded ....... Shell large (up to $25 \mathrm{~mm}$ ), with rapidly increasing whorls; aperture large, more than two times as high as spire; columella ob-

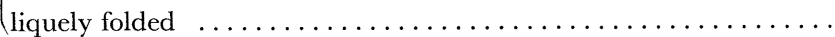

L. tuncatula

L. natalensis

Physa (Physidae)

Bulinus

(see the key)

(Fig. 13)

15 (Fig. 15)

16 (Sphaeriidae)

(Fig. 15)

Corbiculidae

Unionidae

Sphaerium

Pisidium

1 Features in parentheses are those of others than the shell, or supplementary

TABle 4 Key to the genera of common Ethiopian Ancylidae ${ }^{1)}$ (Limpet snails) (Fig. 14)

Shell almost oval or broadly oval, or rather angular in basal shape . . . . 2

$1\{$ Shell relatively narrow, wider in front than behind in basal shape; lateral

sides of shell more or less straight $\ldots \ldots \ldots \ldots \ldots \ldots \ldots \ldots \ldots \ldots \ldots$ Ferrissia

(Shell almost oval or broadly oval in basal shape; apex depressed and

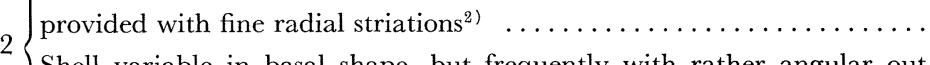

Shell variable in basal shape, but frequently with rather angular out-

line; apex with radial rows of pits ${ }^{2)} \ldots \ldots \ldots \ldots \ldots \ldots \ldots \ldots \ldots \ldots \ldots$ Burnupia

1 Some authors have divided the lipet snails into 2 families, Ancylidae and Ferrissiidae; then the genus Ancylus belongs to the former and Ferrissia and Burnupia to the latter

2 Radial striations and rows of pits can be easily seen by removing the periostracum (epidermal horny layer of shell) by submerging shells in a sodium hypochloride solution 
TABle 5 Key to the genera of Ethiopian Planorbinae (Fig. 13)

(Larger species with a shell more than $3 \mathrm{~mm}$ in height (in thickness)

$1\{$ (except in very young specimens) $\ldots \ldots \ldots \ldots \ldots \ldots \ldots \ldots \ldots \ldots \ldots \ldots \ldots \ldots \ldots \ldots \ldots \ldots \ldots \ldots$ Biomphalaria)

Small species, less than $2 \mathrm{~mm}$ high $\ldots \ldots \ldots \ldots \ldots \ldots \ldots \ldots \ldots$

(Shell size, more than $20 \mathrm{~mm}$ in full grown specimens; whorls $51 / 2-$

$61 / 2$ in number, more closely coiled; upper side of whorls flat . . . . B. sudanica

2 Shell size, less than $20 \mathrm{~mm}$ in full grown specimens; whorls $5-51 / 2$

in number, not so closely coiled as sudanica; upper side rounded or

angular, or partly flat $\ldots \ldots \ldots \ldots \ldots \ldots \ldots \ldots \ldots \ldots \ldots \ldots \ldots \ldots \ldots \ldots \ldots \ldots$ p. peifferi rueppellii

3

Shell serrated in contour and minute in size $(2-3 \mathrm{~mm}) \ldots \ldots \ldots$ Armiger crista ${ }^{1)}$

Shell without serrated contour ................. 4

(Shell flat or concave on both sides with only slightly embracing

4\{

Shell lens-shaped or convex above and flat below; whorls deeply

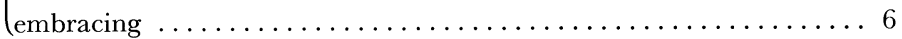

Shell consists of $4-5$ slowly increasing whorls $\ldots \ldots \ldots \ldots \ldots \ldots$ Anisus

5 Shell consists of 3-4.5 more rapidly increasing whorls; (verge with

stylet, pear-shaped at base) $\ldots \ldots \ldots \ldots \ldots \ldots \ldots \ldots$ Gyraulus

6 Shell without internal lamellae $\ldots \ldots \ldots \ldots \ldots \ldots \ldots \ldots \ldots \ldots$ Lentorbis

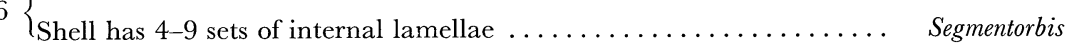

1 This species is very small and of rare occurrence in Ethiopia, which is not shown in Fig. 13

TABle 6 Key to the species of Ethiopian Bulinus (Fig. 13)

1

Shell highly turreted; spire high; (radular teeth small) . . . 3 (forskalii group)

Shell not highly turreted; spire not so high $\ldots \ldots \ldots \ldots 2$

2

Columella truncate in lower portion

Columella not truncate

............ 4 (africanus group)

(Subgenus Physopsis)

6 (truncatus \& tropicus groups)

Shell greater; spire thicker; aperture larger; lower whorls

3\{

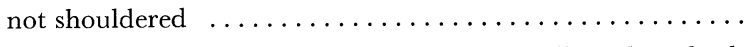

Shell smaller; spire narrower; aperture smaller; the whorls

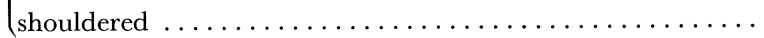

Whorls flattened near suture to form no or blunt shoulder;

spiral microsculpture well developed especially on apex;

4 inner edge of aperture folded well over umbilicus, which

completely open $\ldots \ldots \ldots \ldots \ldots \ldots \ldots \ldots \ldots \ldots \ldots \ldots \ldots \ldots \ldots \ldots$

Whorls shouldered; upper angle of aperture obtuse ..... 5

Whorls shouldered near suture; especially the upper angle of aperture obtuse and frequently of a right-angle; microsculpture fine, never consisting of well defined nodules; inner edge of aperture folded narrowly over umbilicus which

5 is open
B. (B.) scalaris $^{1)}$
B. (B.) forskalii

B. (P.) africanus ovoideus
B. (P.) ugandae 
5 Whorls convex and shouldered; upper angle of aperture is obtuse, microsculpture in upper part of shell is finely corrugate rather than spirally sculptured; inner edge well folded over umbilicus; colour of shell varying from pure

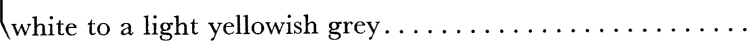

B. (P.) abyssinicus ${ }^{2)}$

(Ultimate (or body) whorl relatively large and spire larger than in the following species; spiral sculpture occasionally present; colour of shell horny brown ..............

6 Ultimate whorls large; spiral sculpture well developed on B. (B.) sericinus apex in many cases and occasionally present in ultimate whorl also; shell colour of living snails pale straw-coloured or

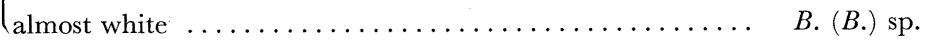

1 Intermediate form of these two species has been found in Ethiopia and another small species belonging to forskalii group, B. reticulatus reticulatus, is restrictedly distributed in the Begemeder province ( $37 \mathrm{~km}$ south of Gondar) and is like those of truncatus group in shape (Brown, 1967)

2 The distribution of this species is restricted in the Lower Awash Valley (Assaita, Gewani, etc.)

3 Bulinus sp. from Lake Awasa was proposed by Burch (1964) to belong to the tropicus group

\section{Discussion}

Surveys had insufficiently conducted on the distribution of human schistosomiasis in Ethiopia. Broadly speaking, Schistosoma mansoni infection was found mainly in the highland areas, but has also been reported to be endemic in the Lower and Upper Awash Valley (Lemma, 1969). Namely, this infection was recorded from Asmara, Decamere, Maaraba, Saganeiti and Adi Ugri in Eritrea, Bahar Dar in the Gojjam province (Ayad, 1956), Harrar in the Harrar province (Ayad, 1956), Tessenei in Eritrea (Nutrition Survey, 1959), Gorgora north of Lake Tana in the Begemder province, Adua in the Tigre province (Duncan, 1970), the regions along the Gojeb river near Bonga (Oliver and Buzo, 1964) and around the lakes of Awasa, Langano and Ziway (Oliver and Buzo, 1964; Ito et al., 1973), and the Akaki and Adami Tulu districts (Ito et al., 1973). On the other hand, urinary schistosomiasis is mainly restricted to the warm and arid lowlands such as the Middle and Lower Awash Valley and the endemic foci were reported in the Gewani and Awash districts (Russell, 1958; Lo, 1970a, b), though immigrated patients have been detected in Addis Ababa, Massawa, Tessenei and other regions.

Bulinines act as the intermediary hosts of Schistosoma haematobium and Biomphalaria snails are those of S. mansoni. Experimental infections of Biomphalaria and Bulinus snails with $S$. mansoni and $S$. haematobium respectively have yielded divergent results. This appears to be caused by the difference in susceptibility of the different species, 
subspecies or local populations of the snails to the different strains of the schistosomes.

The genus Bulinus is usually divided into two subgenera Bulinus and Physopsis, though another subgenus Pyrgophysa may be added to the above two. By the way, four species groups of Bulinus were proposed by Mandahl-Barth (1958) instead of the subgenus system and he considered the 4-group system was the better classification method in view of parasite-host relationship. The four groups are the africanus, tropicus, truncatus and forskalii; and the first group belongs to the subgenus Physopsis and the rest to the subgenus Bulinus. If the subgenus Pyrgophysa is considered to be valid, the fourth group belongs to it. The africanus group, confined in distribution to the Ethiopian geographical region (south of the Sahara), contains important hosts of the schistosomes with terminalspined eggs including $S$. haematobium in the African continent. The truncatus group involves the host species of human and cattle schistosomes. On the other hand, the tropics group has not been known to be the hosts for the schistosomes and the forskalii group contains only two species implicated as the snail host of the urinary schistosome in the African continent (Mandahl-Barth, 1958; Wright, 1966), hence these two groups are generally of little importance as the vector snails of the human schistosomes. All the four groups will occur in Ethiopia, if the species "sericinus" is considered to belong to the truncatus group by means of the features in the radula, mantle pigmentation, reproductive maturity and proportion of euphallic specimens as stated by Brown (1965) and Wu and Burch (1973), and a Bulinus species from Lake Awasa, tentatively considered by Brown (1965) a member of the truncatus group, rather belongs to the tropicus group by the fact that it has haploid chromosome number $(n=18)$ (Burch, 1964). Of the four groups the africanus and truncatus groups will be most suspected for transmission of human urinary schistosomiasis. The sole incriminated host of $S$. haematobium in Ethiopia is $B$. abyssinicus (Lo, 1970a, b), which is also responsible for the infection in Somalia. In addition to this species $B$. africanus ovoideus and B. ugandae, both belonging to the africanus group, occur in Ethiopia. The former species is responsible for transmitting S. haematobium in Kenya (Teesdale, 1962), while the latter is not the host of the blood fluke in Uganda, the Lake Region of Tanzania (Cridland, 1955) and Kenya (Teesdale and Nelson, 1958). Hence B. africanus ovoideus may act as the host in Ethiopia too.

Bulinus sericinus had been considered to be a suspected vector of the urinary schistosome which has been recorded from a broad range of the Ethiopian plateau up to $2,900 \mathrm{~m}$ elevation (Brown, 1964a, b, 1965), but the incrimination of this species will require further verification. Lo (1972) failed to infect Bulinus sp. $(n=18)$ from Lake Bishoftu near Debre Zeit and from Asmara with the Egyptian strain of $S$. haematobium, but recently B. sericinus from its type locality (the Toquor river at Kekerka, Ethiopia) was successfully infected with the Egyptian and Iranian strains by $\mathrm{Wu}$ and Burch (1973). The so-called "Bulinus sericinus" from the Ethiopian highlands, furthermore, has been known to include a few polyploids (Burch, 1967a, b, 1972; Brown and Burch, 1967), of which an octoploid bulinine B. octoploidus was infected with the endemic strain of the blood fluke at a rate of $7 \%($ Lo, 1972).

One of the considerable reasons for the different results of infection trials is that $S$. haematobium has local strains or might wrongly contain other related species. LeRoux (1958) stated that the schistosome infecting the truncatus group was $S$. 
haematobium and that from the africanus group was S. capense (Harley, 1964), and the local strains of $S$. haematobium and $S$. capense were reported by Wright (1962). Another reason is present in complexity of identifying host snails. Bulinus $(P$.) africanus, for example, is discriminated with difficulty from $B .(P$.$) globosus by means of shell$ characters alone, but reliably done by the characters of the copulatory organ (Wright, 1973). Identification used by Brown (1965) of the Ethiopian freshwater snails was principally followed in the present paper and only shell characters were used for identification. But, other characteristics must be utilized in further study, for differences in immuno-cytological patterns are present between different Bulinus populations (Burch and Lindsay, 1970).

Biomphalaria snails containing the vectors of $S$. mansoni are divided into four species groups: the pfeifferi, sudanica, alexandrina and choanomphala, of which the first two have been reported from Ethiopia (Ayad, 1956; Wright and Brown, 1962; Brown, 1965). B. pfeifferi and its subspecies have been confirmed as the hosts of S. mansoni (Teesdale and Nelson, 1958; LeRoux, 1961; Webbe, 1962a, 1965; Ito et al., 1973b). But, field and experimental infections of $B$. sudanica and its subspecies with S. mansoni revealed that this species varied in susceptibility to the local strains of the parasite (McClelland, 1956; Webbe, 1962a, 1965; Wright, 1962) and, at least in Ethiopia, is not so much responsible for transmitting the parasite (Ito et al., 1973).

Considering the distributions of the blood fluke diseases and of the vector snails and the susceptibility of the snails to the parasites, the most predominant host snails of $S$. mansoni in Ethiopia will be Biomphalaria pfeifferi rueppellii and the only host of $S$. haematobium incriminated by field and experimental examinations is Bulinus abyssinicus which is principally distributed in the Gewani district of the Lower Awash Valley. In addition to this species of snail, B. africanus ovoideus might be a responsible host in Ethiopia. Consequently it will be highly possible that schistosomiasis haematobium becomes endemic in the highlands, when the northern African or Near Eastern urinary schistosome strain would be introduced into the highlands, as surmized by Wu and Burch (1973).

Identification keys have been prepared by previous authors of the intermediate snail hosts of blood flukes and the related species of snail for physicians and veterinarians' use, and Mandahl-Barth (1962a) dealt with the East and Central African freshwater snails and Meskal (1967) with the Ethiopian freshwater gastropods. Meskal's key is not pictorial, with insufficient explanation of terms and with a few mistakes.

Main ecological factors responsible for marked changes in abundance of freshwater snails will be temperature and rainfall in sub-tropical and temperate regions, but in the tropical arid regions such as Sudan and the coastral plain of Tanzania it is only the high temperature of summer that appears to reduce the reproduction (Malek, 1962). The maximum temperature for Biomphalaria pfeifferi appears to be about $32 \mathrm{C}$, but the colonies might not survive temperatures much above $28 \mathrm{C}$ under field conditions (Sturrock, 1966). The optimum temperature for rapid population expansion of $B$. pfeifferi and Bulinus globosus is close to $25 \mathrm{C}$, and at other temperatures the snail expands population much more slowly, surviving favourably at $19 \mathrm{C}$ and not at 30 C (Shiff 1964; Harrison and Shiff, 1966; Sturrock, 1966). Biomphalaria 
and Bulinus snails will be able to tolerate the climatic condition in Ethiopia except very high altitudes of the plateau, but the low temperature might inhibit the development of the intramolluscan stages of blood flukes to limit the distribution of schistosomiasis in the country. The data on prepatent periods obtained from experimental infection with $S$. haematobium conducted in outdoor aquaria in South Africa showed that transmission in natural habitats in this area was curtained during the four coldest months of the year when the mean maximum temperature is about $20 \mathrm{C}$ or less (Pitchford and Visser, 1965). Monthly mean temperatures in Addis Ababa during 1959 and 1967 ranged from 13.6 to $16.4 \mathrm{C}$ with an average of $13.0 \mathrm{C}$; and monthly means of maximum temperature were 18.9 to $23.3 \mathrm{C}$ with an annual average of $21.0 \mathrm{C}$ and those of mean minimums 6.2 to $10.2 \mathrm{C}$ with an average of $5.8 \mathrm{C}$ (The Geographical Observatory, Haile Sellasie I Univ.).

As to the alkalinity of habitats Watson (1958) mentioned that establishment and multiplication of Bulinus truncatus was favoured by neutral or slightly alkaline water, and hard water was better than soft one. In the present survey Bulinus was found more abundantly in slightly acid waters, whereas Biomphalaria was more abundant in slightly alkaline waters. Bilharziasis vectors appear to tolerate a wide range of $\mathrm{pH}$, generally speaking, from 6.0 to 9.0 (Malek, 1958).

In Tanzania Bulinus nasutus rapidly increases in population after the start of rainy season (Webbe, 1962a) and B. globosus responds to rainfall by very active breeding in Rhodesia (Shiff, 1964). The same phenomenon was observed in the case of B. truncatus rohlfsi in Ghana. Biomphalaria sudanica is flushed out of its stream habitats by rains and reaches high densities only during the dry season (Webbe, 1962a). Bulinus breeds, in general, more rapidly than Biomphalaria under favourable conditions and bulinines were frequently found in Ethiopia at temporary waters such as road-side pits from which clay had been taken for making houses.

Another important factor affecting snail distribution may be water current. Bulinus truncatus does not occur in rapidly flowing waters; a rate of 20 to $30 \mathrm{~cm} / \mathrm{sec}$ is approximately the maximum in which this species is found (Watson, 1950, 1958) and the distribution of B. glabrata (=Australorbis glabrata) and B. alexandrina was also observed to be seriously influenced by stream gradient (Harry and Cumbic, 1956; Pimentel and White, 1959a). Most of large and permanent rivers in the Ethiopian plateau such as the Gibe river on the Jimma road and the Awash river near Awash and Mojo were hardly populated by Bulinus and Biomphalaria snails, probably owing to rapid current and absence of deposited organic materials.

Changes in the distribution and abundance of vector snails have been reported to be produced by reclamation and rehabilitation of lands which bring about migrations of people and domestic animals, construction of small reservoirs and irrigation channels, damming of streams and mild pollution of waters. In the Aswan province of Egypt the amount of S. haematobium infection increased from four- to 40-fold in three years following the substitution of the perennial type of basin irrigation (Wright, 1973). Watson (1958) reported Bulinus truncatus was abundant in waters polluted to some extent by human excrement, but was conspicuously absent from areas heavily polluted with animal excrement. In Ethiopia the largest dam is situated at Koka on the Awash river near Nazareth, which was constructed to supply water to power 
mills and for irrigation, and the Koka reservoir (Lake Koka) was inhabited by a great number of Bulinus, Biomphalaria, Lymnaea and the related pulmonate snails. On executing developing plans the endemic foci of schistosomiasis will possibly spread over the country, as suggested by Ayad (1956).

Some kinds of plants have been frequently observed associated with a peculiar species of freshwater snail. A large part of the association of snails and plants is said to be brought about by the common cause of generally favourable aquatic habitats, rather than to cause and effect (Watson, 1958); but it may be sure that vegetation provides good surface for snails to feed on and to spawn. The food of freshwater snails is algae, especially diatomes, or a combination of this and decaying vascular plants (Watson, 1958; Dazo and Moreno, 1962). A blue green alga, Oscillatoria formosa, was proved to be a very satisfactory diet for rearing Bulinus (Xavier et al., 1968).

The following species of plants have been reported to be associated with Bulinus and Biomphalaria: Nymphaea, the water hyacinth, Potamogeton crispus, Potamogeton spp., Callitriche, Polygonum, the rush, Ranunculus, Carex, etc. The snails are not always associated with a specific species of aquatic animals, but a certain species of mayfly was observed as an indicator of the habitats of Biomphalaria pfeifferi and Bulinus africanus in South Africa (de Meillon et al., 1958).

\section{ACKNowledgement}

The authors wish to express their sincere thanks to Drs. T. Ishizaki and S. Asahina, the National Institute of Health in Tokyo, for the valuable suggestions rendered during the course of this work. Thanks are also due to Drs. T. Ohse, K. Ogata, K. Kaneko, N. Takahashi and K. Saito, the former members of the Japanese Medical Cooperation Team to Ethiopia, and Dr. C. T. Lo who was a visiting research worker of the Institute of Pathobiology, Haile Sellasie I University in Addis Ababa, for collecting the materials and encouragement and also to Dr. T. Aseffa, the former director of the Imperial Central Laboratory and Research Institute in Addis Ababa, for his interest shown during the survey.

\section{REFERENCES}

1) Ayad, N. (1956): Bilharziasis survey in British Somaliland, Eritrea, Ethiopia, Somalia, the Sudan and Yemen, Bull. Wld Hlth Org., 14, 1-117

2) Brown, D. S. (1964a): The distribution of intermediate hosts of Schistosoma in Ethiopia, Ethiop. Med. J., 2, 250-259

3) $(1964 \mathrm{~b})$ : Observation on the distribution and ecology of freshwater gastropod mollusca in Ethiopia, Contr. Facul. Sci. Haile Sellasie I Univ. Ser. C (Zool.), No. 5-6, 9-40

4) (1965): Freshwater gastropod mollusca from Ethiopia, Bull. Brit. Mus. (Natl. Hist.) Zool., 12, 39-94

5) (1967): Records of Planorbidae new for Ethiopia (Gastropoda, Pulmonata), Arch. Moll., 96 (3/6), 181-185

6) Brown, D. S. and Burch, J. B. (1967): Distribution of cytologically different populations of the 
genus Bulinus in Ethiopia, Malacologia, 6, 189-198

7) Burch, J. B. (1964): Cytological studies of Planorbidae. I. The African subgenus Bulinus s.s., Malacologia, 1, 387-400

8) (1967a): Chromosomes of intermediate hosts of human bilharziasis, Malacologia, 5, $127-136$

9) $(1967 \mathrm{~b})$ : Some species of the genus Bulinus in Ethiopia, possible intermediate hosts of schistosomiasis haematobium, Ethiop. Med. J., 5, 245-257

10) - (1972): Names for two polyploid species of African Bulinus, Malacol. Rev., 5, 7-8

11) Burch, J. B. and Lindsay, G. K. (1970): An immuno-cytological study of Bulinus s.s., Malacol. Rev., 5, 7-8

12) Cridland, C. C. (1955): The experimental infection of several species of African freshwater snails with Schistosoma mansoni and Schistosoma haematobium, J. Trop. Med. Hyg., 58, 1-11

13) Dazo, B. C. and Moreno, R. G. (1962): Studies on the food and feeding habits of Oncomelania quadrasi, the snail intermediate host of Schistosoma japonicum in the Philippines, Trans. Amer. Microsc. Soc., 81, 341-347

14) de Meillon, B., Frank, G. H., and Allanson, B. R. (1958): Some aspects of snail ecology in South Africa, Bull. Wld Hlth Org., 18, 771-783

15) Duncan, A. (1970): A brief description of schistosomiasis in Ethiopia, OAU Symp. Schistosomiasis, Addis Ababa, 1970, Document, CS/15 (I)

16) Harrison, A. D. and Shiff, C. J. (1966): Factors influencing the distribution of some species of aquatic snails, S. Afr. J. Sci., 62, 253-258

17) Harry, H. W. and Cubie, B. G. (1956): Stream gradient as a criterion of lotic habitats suitable for Australorbis glabratus in Puerto Rico, Amer. J. Trop. Med. Hyg., 5, 921-928

18) Ito, Y., Itagaki, H. and Teferra, W. (1973): Studies on the susceptibility of Biomphalaria pfeifferi rueppellii and B. sudanica to Schistosoma mansoni in Ethiopia, Jap. J. Trop. Med. Hyg., 1 (1), 1-5

19) Ito, Y., Tada, I., Itagaki, H., Iwamoto, I., Teferra, W. and Aseffa, T. (1973): Epidemiological survey of schistosomiasis in the Rift Valley Lake area, Ethiopia, Jap. J. Parasit., 22 (1, suppl.), $17-18$

20) Lemma, A. (1969): Bilharziasis in Awash Valley. I. An epidemiological study with special emphasis on its possible future ecologic and public health importance, Ethiop. Med. J., 7, 147176

21) LeRoux, P. L. (1958): The validity of Schistosoma capense amended as a species, Trans. R. Soc. Trop. Med. Hyg., 52, 12

22) (1961): Some problems in bilharziasis in Africa and the adjoining countries, J. Helminth., Leiper Suppl., 117-126

23) Lo, C. T. (1970a): Snail intermediate host of Schistosoma haematobium in Ethiopia, OAU Symp. Schistosomiasis, Addis Ababa 1970, Document, CS/30 (I)

24) (1970b): Experimental exposure of Bulinus spp. to miracidia of Schistosoma haematobium from Ethiopia, OAU Symp. Schistosomiasis, Addis Ababa 1970, Document, CS/29 (I)

25) (1972): Compatibility and host-parasite relationship between species of the genus Bulinus and an Egyptian strain of Schistosoma haematobium, Malacologia, 11 (2), 225-280

26) Malek, E. A. (1958): Factors conditioning the habitat of bilharziasis intermediate hosts of the family Planorbidae, Bull. Wld Hlth Org., 18, 785-818

27) (1962): Bilharziasis control in pump schemes near Khartoum, Sudan and an elevation of the efficacy of chemical and mechanical barriers, Bull. Wld Hlth Org., 27, 41-58

28) Mandahl-Barth, G. (1958): Intermediate hosts of Schistosoma: African Biomphalaria and Bulinus, Wld Hlth Org. Mongr. Ser., No. 37, Geneva, 89

29) (1962): Key to the identification of East and Central African freshwater snails of medical and veterinary importance, Bull. Wld Hlth Org., 27, 135-150 
30) (1965): The species of the genus Bulinus, intermediate hosts of Schistosoma, Bull. Wld Hlth Org., 33, 33-44

31) McClelland, W. F. J. (1956): Studies on snail vectors of schistosomiasis in Kenya, J. Trop. Med. Hyg., 59, 229-242

32) Meskal, F. H. (1967): A preliminary identification key to the freshwater gastropod molluscs of Ethiopia with some comments of the medical significance of a few species, Ethiop. Med. J., 5 (4), 227-235

33) Nutrition survey, Ethiopia (1959): A report by the Inter-departmental Committee on Nutrition for National Defense, Department of Defense, Washington D. C.

34) Olivier, L. J. and Buzo, Z. J. (1964): Bilharzia in Ethiopia. Report on a visit to Ethiopia by the Inter-regional Bilharziasis Advisory Team, 4-21 Feb. 1964. WHO unpublished document, $\mathrm{PA} / 231$

35) Pimentel, D. and White, P. C., Jr. (1959): Biological environment and habits of Australorbis glabratus, Ecology, 40, 541-550

36) Pitchford, R. J. and Visser, P. S. (1965): Some further observations on schistosome transmission in the Eastern Transvaal, Bull. Wld Hlth Org., 32, 83-104

37) Russel, H. B. L. (1958): The Pilot Mobile Health Team, Ethiopia, Final report. WHO unpublished document, EM/PHA/62

38) Shiff, C. J. (1964): Studies on Bulinus globosus in Rhodesia. I. The influence of temperature on the intrinsic rate of natural increase, Ann. Trop. Med. Parasit., 58, 94-105

39) Sturrock, R. F. (1966): The influence of temperature on the biology of Biomphalaria pfeifferi, an intermediate host of Schistosoma mansoni, Ann. Trop. Med. Parasit., 60, 100-105

40) Teesdale, C. (1962): Ecological observations on the molluscs of significance in the transmission of bilharziasis in Kenya, Bull. Wld Hlth Org., 27, 759-782

41) Teesdale, C. and Nelson, C. S. (1958): Recent work on schistosomes and snails in Kenya, E. Afr. Med. J., 35, 427-438

42) Watson, J. M. (1950): Studies on bilharziasis in Iraq. Part V. Habitat of the vector snail, Bulinus truncatus and its distribution in relation to the irrigation system, J. Roy. Fac. Med. Iraq, 14, 833-894

43) (1958): Ecology and distribution of Bulinus truncatus in the Middle East, with comments on the effect of some human activities in their relationship to the snail host on the incidence of bilharziasis haematobia in the Middle East and Africa, Bull. Wld Hlth Org., 18, 833-894

44) Webbe, G. (1962): Population studies on intermediate hosts in relation to transmission of bilharziasis in East Africa, Bilharziasis: Ciba Foundation Symposium, 7-22, London

45) (1965): Transmission of bilharziasis. 2. Production of cercariae, Bull. Wld Hlth Org., 33, 155-162

46) Wright, C. A. (1962): The significance of infra-specific taxonomy in bilharziasis, Bilharziasis: Ciba Foundation Symposium, 103-120, London

47) (1966): Relationships between schistosomes and their molluscan hosts in Africa, J. Helminthol., 40 (3/4), 403-412

48) Wright, C. A. and Brown, D. S. (1962): On collection of freshwater gastropod molluscs from the Ethiopian highlands, Bull. Brit. Mus. (Natl. Hist.) Zool., 8 (6), 287-311

49) Wright, W. H. (1973): Geographical distribution of schistosomes and their intermediate host, Epidemiology and control of schistosomiasis, 32-249, University Park Press, Baltimore

50) Wu, S. K. and Burch, J. B. (1973): Experimental infection of Bulinus sericinus with Schistosoma haematobium, Malacol. Rev., 7, 56 


\section{ApPendix}

Collecting loci of freshwater molluscs where ecological observations were made.

Distance in $\mathrm{km}$ shows that from Addis Ababa, when without any notice, and temperatures show those of water. Freshwater snails collected are given in parentheses with abbreviations ( $\mathrm{A}=$ Ancylus sp., $\mathrm{An}=$ Anisus sp., $\mathrm{Ar}=$ Armiger sp., $\mathrm{B}=$ Bulinus (Bulinus) sp., $\mathrm{Ba}=$ Bulinus (Physopsis) abyssinicus, $\mathrm{Bf}=$ Bulinus (B.) forskalii, $\mathrm{Bis}=$ Biomphalaria sudanica, $\mathrm{Bpr}=$ Biomphalaria pfeifferi rueppellii, $\mathrm{Bs}=$ Bulinus $(B$.$) sericinus,$ $\mathrm{Bu}=$ Burnupia sp., $\mathrm{E}=$ Etheria elliptica, $\mathrm{F}=$ Ferrissia sp., $\mathrm{G}=$ Gyraulus sp., $\mathrm{Ln}=$ Lymnaea natalensis, $\mathrm{Lt}=$ Lymnaea truncatula, $\mathrm{M}=$ Melanoides tuberculata, $\mathrm{P}=$ Pisidium $\mathrm{sp} ., \mathrm{Ph}=$ Physa sp., $\mathrm{S}=$ Sphaerium sp., $\mathrm{Se}=$ Segmentorbis sp., $\mathrm{V}=$ Valvata $\mathrm{sp}.) . \quad$ "Bulinus sericinus" (Bs) may contain the related polyploid species.

1. Along the road from Addis Ababa to Asmara via Dessie

River Ordida near Koba, 100 km, 13 C, pH 6.8, (Ln, An, G, Bpr, Bs, V, Bu); River Chacha near Chacha, $110 \mathrm{~km}, 18.0 \mathrm{C}, \mathrm{pH}$ 6.8, (Bpr, Bs, An, V, A); A pool by River Baresa near Debre Berhan, 21.5 C, pH 6.8, (Bs, An); River Baresa near Debre Berhan, about 130 km, 21.0 C, pH 7.4, (G, An); Lake Gorbo (=L. Gobara) in Gorbo Village north of Dessie, 24.0 C, pH 7.6, (Bpr, Bs, Ln); A stream near the slaughter house in Kembolcha, (Bpr); Lake Haik, 24.0 C, pH 8.2, (Bs, G); River Tita in Tita Village near Dessie, 665-670 km, 16 C, pH 6.8, (Bs, An); River Haik in Haik Village, (Ln, Bpr); River Keralu, 19.0 C, pH 7.6, (Bpr, Bs, Ln); River Ajowa in Wuchale Village, 23.5 C, pH 7.2, (Bpr); River Silinga in Silinga Village, 23.0 C, pH 7.0, (Bpr); River Borchenna in Kembolcha, $365 \mathrm{~km}, 21.0 \mathrm{C}$, (Ln, Bpr); River Wolke in Kamise Village, 315 km, 22.5 C, pH 7.4, (Bs, Bpr); River Artuma Bilu near Mita, about $303 \mathrm{~km}, 25.0 \mathrm{C}$, pH 7.6, (Bis, Ln, An); River Senbete near Senbete, about 256 km, 25.5 C, pH 7.6, (Bpr); River Sibilu (a tributary of R. Mugher) in Chancho Village, about $50 \mathrm{~km}$, (A); River Damotu in Chancho, about $55 \mathrm{~km}$, (Bpr, Bs, A, G, $\mathrm{S}, \mathrm{V}, \mathrm{Bu}$ ); River Alellu in Chancho, about $60 \mathrm{~km}$, (Bpr, Bs, An, G, S); A stream, 35-40 km, 20.0 C, pH 5.6, (Lt, A); River Ubebarha, $11 \mathrm{~km}, 15.0 \mathrm{C}, \mathrm{pH}$ 5.6, (A); A stream between Chacha and Debre Berhan, 120-125 km, 9.5 C, pH 5.4, (A); River Kabigiza, 115-120 km in Chacha Village, $11.0 \mathrm{C}$, pH 5.4, (S, Bs, An, Bs); River Chacha in Chacha Village, $110 \mathrm{~km}, 16.0 \mathrm{C}, \mathrm{pH}$ 5.6, (Bpr, Bs, An, G, V, S); River Ordida in Chacha Village, $100 \mathrm{~km}, 14.5 \mathrm{C}, \mathrm{pH}$ 5.4, (An, G, Ln, Bu, Bs); A pool, $75 \mathrm{~km}, 18.0 \mathrm{C}$, pH 5.6, (Bs); River Jisa, 70-75 km, in Sheno Village (Amsgaba Saraishu), 18.0 C, pH 5.6, (An, Bpr); A stream near Yegudo, 65-70 km, in Yegudo Village, 16.0 C, pH 5.8, (Bs, Bpr, Lt); A stream, 65 km, 16.0 C, pH 5.6, (Bpr, Bs, An, S); A stream in Alelfu Village, 60-65 km, 17 C, pH 5.8, (G); River Kamte in Alelfu Village, 55-60 km, 20.0 C, pH 5.4, (Bpr); New Reservoir of Addis Ababa, $30 \mathrm{~km}, 20.5 \mathrm{C}$, pH 5.6, (Bs, Bpr, An); A stream $5 \mathrm{~km}$ from Kekere, (Bpr); River Borkena, (Bpr, Ln, Bu, P); A stream between Makale and Enda-Sellasie, (Bpr, Ln, Bs, An); River Atai near Atai Town, (G)

2. Along the road from Addis Ababa to Dire Dawa and Erer via Nazareth

Awash Fall in Awash Natl. Pk., (Bu, M, Unionidae); Hot Spring in Awash Natl. Pk., (M, An); River Hiruna in Hiruna Village, 365-370 km, 27.0 C, pH 7.6, (Bpr); 
A pool (Hubeta), 390-395 km, 19.5 C, pH 6.8, (small planorbids); River Erer in Erer, 400-405 km, 30.0 C, pH 7.8, (Lt); River Harawe, 535 km, 23.0 C, pH 7.8, (Bpr); A pool near Babile, 555 km, $21.0 \mathrm{C}$, pH 7.8, (Bs); Lake Alem Maya in Agriculture College, 20.0 C, pH 7.2, (Ln, Bs); Lake Alem Maya near Agriculture College, 515 km, $29.5 \mathrm{C}, \mathrm{pH}$ 7.8, (Ln, Bs, An, Bpr); Lake Alem Maya in Alem Maya Village, 505 km, $26.5 \mathrm{C}, \mathrm{pH} 7.8$, (Bs); A small deep pool by Lake Adele, $500 \mathrm{~km}, 21.5 \mathrm{C}, \mathrm{pH} 7.6$, (Ln, Bs); River Chalenko, about 445 km, $17.0 \mathrm{C}$, pH 7.6, (Bpr, Lt, Ln, small planorbids); River Akaki in Akaki Village near Addis Ababa, 20.0 C, pH 6.8, (Bs, Unionidae); Lake Chalalaka, $45 \mathrm{~km}, 22.0 \mathrm{C}, \mathrm{pH} 7.1$, (Bs); Lake Bishoft in Debre Zeit, 24.0 C, pH 9.3, (Bs); Lake Hora Orsendi in Debre Zeit, 24.5 C, pH 9.5, (Bs); Lake Babogaie near Debre Zeit, 26.0 C, pH 8.9, (Bpr, Bs, An, Ln, G, V; all the shells empty, except for 2 Bulinus snails); A small stream flowing into Lake Chilotes near Debre Zeit, 28.0 C, pH 6.8, (Bpr, Ln); Lake Chilotes, $\mathrm{pH}$ 6.6, (small planorbids); River Mojo crossing the road near Mojo, 24.0 C, pH 6.8, (G, F, P); A small pool in Koka Hotel in Koka, $(\mathrm{Ph})$; Gewani in Harrar province, $(\mathrm{Ba})$

3. Along the road from Addis Ababa to Adigrat via Bahar Dar and Axum

River Deneba, 5-10 km, 14.0 C, pH 6.0, (F); River Dima in Sululta (?) Village, 20-25 km, 15.0 C, pH 6.0, (Bs, An, Bu, F); River Ragateruma in Gabra Gracha Village, 135-140 km, 14.0 C, pH 5.4, (F); River Dadausarubi near Dagamu, 125$130 \mathrm{~km}, 13.5 \mathrm{C}, \mathrm{pH} 5.4$, (Bs, An, P); A stream, 125-130 km, $14.0 \mathrm{C}, \mathrm{pH} 5.4$, (An, $\mathrm{P})$; A stream, $115-120 \mathrm{~km}, 18.0 \mathrm{C}, \mathrm{pH} 5.6$, (Lt); A stream, 110-115 km, $18.0 \mathrm{C}$, pH 5.6, (Bs, Bpr); River Guru near Debre Libanos, 21.0 C, pH 6.8, (Bs, G, Bpr); River Wasarbu, 18.0 C, pH 5.4, (Bpr, Bu, S, V); River Nagaljele, 45-50 km, 13.5 C, pH 5.4, (Bpr, Bs, G, V); River Adillo, 20-25 km, 14.0 C, pH 6.0, (Bs); River Sululta, (Bs, Bpr, Bu, An, G, Lt, Ln, V, S, P); River Chagel near Debre Libanos, (Bpr); River Ijere Ragagora, (Bpr, G, Bs); River Duber, (Bpr, G, An, Lt); River Chancho near Chancho, (P); A stream between Enda-Sellasie and Gondar, (Bpr)

4. Along the road from Mojo to Awasa via Shashamane

Lake Koka (Koka Reservoir Lake, Lake Galila), 25.0 C, pH 7.0, (Ln, Bs); River Redjebo in Goldjota Village, 24.0 C, pH 5.8, (Lt); River Redjebo, 16.0 C, pH 5.8, (Bs); River Buccanisa in Goldjota Village, 15.5 C, (F, Bu); Lake Shalla, 23.0 C, pH 10.4, (M, Bs, Bpr, V; all the shells empty); River Dadabbu, 18 km from Negelle to Shashamane in Negelle Village, (P); River Garbite, $18.0 \mathrm{C}$, pH 5.6, (Bu); River Laftu between Adami Tulu and Shashamane, 18.0 C, pH 5.6, (A, Ar); Lake Langano, (M, Corbiculidae; all the shells empty); River Markaoda, 22.0 C, pH 5.6, (Bs, S) ; Lake Abiata, (M; all empty shells); River Wosha at Hydrogical Station No. 4 (MNCD Awasa Farm), 19.5 C, pH 5.8, (An, Lt, P); River Wolka, 20.0 C, pH 6.0, (P); River Karo, 18.0 C, pH 5.6, (An); River Kella near Philadelphia Mission Clinic, 19.0 C, pH 5.4, (Bpr, Lt, P); River Gomoso at Hydrogical St. No. 8, 17.0 C, pH 5.6, (Bpr, An, P, Lt); River Wodessa, 18.5 C, pH 5.4, (P, A); River Abowassa, (Sphaeriidae); A small stream in the swamp (Marge Wando), $24.0 \mathrm{C}$, (An, Se); A pool near Black Water River, 21.0 C, pH 6.0, (Bis); A pool (Oa) in Sciella Swamp, 21.5 C, pH 6.6, (An); Lake Awasa (Daleti), north shore, 25.0 C, pH 6.6, (Ln, Bis, B, Bf, An); Lake Awasa, east shore, $1 \mathrm{~km}$ from a petrol station, 23.0 C, pH 6.2, (Bpr, Ln, B); Lake Awasa, east shore, $25 \mathrm{C},(\mathrm{Bf}, \mathrm{B}, \mathrm{An})$ 
5. Along the road from Addis Ababa to Jimma and Bonga

River Fuleha (R. Sabata), 20-25 km, 22.0 C, pH 5.6, (F); River Rebiur between Ghion and Jimma, (A); River Awash crossing the road, (Bs, An); Tadji, (Bs); A stream near Bonga, (Ln); River Ejiasar, (F); River Gibe, (M, Corbiculidae)

6. Along the road from Addis Ababa to Ambo and Nekempt

A stream from Water Reservoir of Addis Ababa, 20-25 km, 16 C, (Bs, small planorbids); River Hobi, 25-30 km, 16 C, (Lt, Bs, Bu); River Wolmera, 35-40 km, 17 C, (Lt, P); River Urunie, 35-40 km, 17 C, (Bpr, G, Bu, P); River Gale, 40-45 km, 21 C, (Bs, Bpr, An) ; River Birgi, 40-45 km, 18.5 C, (Bu); River Worofe, 65-70 km, 24 C, (Bpr); River Wuluko, 65-70 km, 22.5 C, (Bpr, small planorbids); River Abadebela, 65-70 km, 20.0 C, (Bpr); River Chenktu, 70-75 km, 23 C, (Ln, Bpr, An, Bu, P, Lt); River Danjab, 75-80 km, (A, G); River Bore, 100-105 km, (Bpr, Bs, small planorbids); River Hedie (=R. Guder) near Guder, 140-145 km, 20.0 C, (Bpr, An, A, G, P); River Awaro near Ambo, 120 km, 22.5 C, (Bpr, small planorbids); River Sorbie, 115-120 km, 26 C, (Bpr); River Meti, 110-115 km, 19.5 C, (Bs); River Bukisa, 110 $115 \mathrm{~km}, 24.5 \mathrm{C}$, (Lt, An); River Gova (?), $30 \mathrm{~km}, 16.0 \mathrm{C}, \mathrm{pH} 7.2$, (Lt, Bpr, G, Bs, $\mathrm{Bu})$; A stream in a stock farm, about the midst of Holeta River and Holeta Village, 16.0 C, pH 7.2, (Bpr, Bs, An, P); River Chancho, 30-35 km, 18.0 C, pH 5.4, (Lt); River Wolemera, $37 \mathrm{~km}, 16.0 \mathrm{C}, \mathrm{pH}$ 5.6, Swampy habitats near the stream, (P); River Suba, $10 \mathrm{~km}$ from Holeta on a road branching off from the main road, (Bs, $\mathrm{A}, \mathrm{Lt})$; River Awaro in Awaro Chabe Village, 115-120 km, $17.0 \mathrm{C}, \mathrm{pH} 5.6$, (Bu, G, P, F); River Sorbe, $115 \mathrm{~km}$, in Ambo (Agere Hiwot) Village, 22.0 C, pH 6.2, (Bpr); River Mete, $115 \mathrm{~km}, 15.5 \mathrm{C}, \mathrm{pH}$ 5.4, (Bpr, Bs, G, Bu); River Boren, 100105 km, 26.0 C, pH 5.8, (Bpr); River Janjab, 75-80 km, 18.5 C, pH 5.4, (G, A); River Kere near Wolencomi, 70-75 km, 14.0 C, pH 5.6, (Bpr, G); River NachoJanketobara near Ihud Gebeya, 70-75 km, 14.0 C, pH 5.6, (Bpr); River Abadebela, 65-70 km, 13.0 C, pH 5.8, (Bpr, Lt); River Berga, 55-65 km (?), $16.0 \mathrm{C}, \mathrm{pH} 6.6$, (A); A stream, 50-55 km, 16.0 C, pH 5.4, (P); A small stream in Jakob Stock Farm near the Imperial Central Laboratory \& Research Institute, Addis Ababa, (Bu); River Bomba, (Bpr, Lt) 


\author{
エチオピア産淡水貝類の研究, 特に人寄生住血吸虫の \\ 中間宿主貝の同定，分布および生態 \\ 板垣 博 $^{1} \cdot$ 鈴木了司 ${ }^{2} \cdot$ 伊藤洋一2 \\ 原 隆昭 ${ }^{3} ・$ テェラ ウオンデ4
}

1969年 1 月より1971年 1 月にわたる期間にエチオピア各地で，マンソン住血吸虫およびビルハルッ住 血吸虫の中間宿主貝に重点をおいて数度にわたる採集をおこない，これらの中間宿主貝の分布および生 息条件を調査した。採集された腹足類（巻貝類）は2目（前鰓目および有肺目）からなり，前鰓目には 3 科が含まれ，有肺目には 4 科が認められた。また，斧足類（二枚貝類）には 4 科が含まれていた (Table 1)。エチオピアにおいては Biomphalaria pfeifferi rueppellii と Bulinus (Physopsis) abyssinicus とが，それぞれマンソン住血吸虫およびビルハルッ住血吸虫の最も重要な中間宿主である。エチオピア における淡水貝類の分布には 2 つ型がみられ，1つは全土に広く分布するすの（広布種）と他は散在 するものである。Biom. pfeifferi rueppellii と Bulinus (Bulinus) sericinus とは前者の型に属し(Figs. 2, 3), Biomphalaria sudanica やBulinus 属のPhysopsis 亜属に属する各種など (Figs. 5, 6) は後者にはい る。淡水貝の同定は困難なことが多く, 住血吸虫症の研究者のためにエチオピア産淡水貝の検索表 (Tables 3, 4, 5, 6) および検索図（Figs. 12, 13，14，15）在作成した。淡水貝の分布を左右する生態学的 条件としては，降雨および生息地の栄養的条件（慨料の多少）が水温や $\mathrm{pH}$ なよりも重要であり， た水流も重要な条件となることがある。地域の開発にともなう人の移住によって水域が排泄物や家庭廃 水によって軽度に污染されると中間宿主貝にとって好適な生息場所を提供することとなり，これらの地 点が新しい住血吸虫症の流行地となる可能性がある。

1 麻布獣医科大学寄生虫学教室 2 国立予防衛生研究所寄生虫部 3 予防医学協会, 東京都 4 工チ オピア帝国中央研究所医動物学部 